\title{
A review of the epidemiological and clinical aspects of West Nile virus
}

This article was published in the following Dove Press journal:

International Journal of General Medicine

II April 2014

Number of times this article has been viewed

\section{Timothy J Gray' \\ Cameron E Webb ${ }^{2,3}$}

'Department of Infectious Diseases, St Vincent's Hospital, Darlinghurst, NSW, Australia; ${ }^{2}$ Department of Medical Entomology, Centre for Infectious Diseases and Microbiology and Pathology West - Institute of Clinical Pathology and Medical Research, Westmead, NSW, Australia; ${ }^{3}$ Marie Bashir Institute for Infectious Diseases and Biosecurity, University of Sydney, NSW, Australia
Correspondence: Timothy J Gray Department of Infectious Diseases, St Vincent's Hospital, 390 Victoria Street Darlinghurst, 2010, NSW, Australia Tel +6I 28382 I III

Email tim.gray@tpg.com.au
Abstract: The resurgence of West Nile virus (WNV) in North America and Europe in recent years has raised the concerns of local authorities and highlighted that mosquito-borne disease is not restricted to tropical regions of the world. WNV is maintained in enzootic cycles involving, primarily, Culex spp. mosquitoes and avian hosts, with epizootic spread to mammals, including horses and humans. Human infection results in symptomatic illness in approximately one-fifth of cases and neuroinvasive disease in less than $1 \%$ of infected persons. The most consistently recognized risk factor for neuroinvasive disease is older age, although diabetes mellitus, alcohol excess, and a history of cancer may also increase risk. Despite the increasing public health concern, the current WNV treatments are inadequate. Current evidence supporting the use of ribavirin, interferon $\alpha$, and WNV-specific immunoglobulin are reviewed. Nucleic acid detection has been an important diagnostic development, which is particularly important for the protection of the donated blood supply. While effective WNV vaccines are widely available for horses, no human vaccine has been registered. Uncertainty surrounds the magnitude of future risk posed by WNV, and predictive models are limited by the heterogeneity of environmental, vector, and host factors, even in neighboring regions. However, recent history has demonstrated that for regions where suitable mosquito vectors and reservoir hosts are present, there will be a risk of major epidemics. Given the potential for these outbreaks to include severe neuroinvasive disease, strategies should be implemented to monitor for, and respond to, outbreak risk. While broadscale mosquito control programs will assist in reducing the abundance of mosquito populations and subsequently reduce the risks of disease, for many individuals, the use of topical insect repellents and other personal protective strategies will remain the first line of defense against infection.

Keywords: flavivirus, public health threat, mosquitoes

\section{Introduction}

West Nile virus (WNV) is a mosquito-borne pathogen of concern to health authorities internationally. The virus poses an emerging threat to public health in many parts of the world, and over the past decades, there has been substantial and rapid geographical spread. Although the clinical spectrum of disease is broad in humans, a small proportion of patients will develop neuroinvasive disease associated with significant morbidity and mortality. There is still much to be unraveled regarding the intricacies of the environmental, entomological, zoological, and anthropological drivers of the outbreaks. Treatment is generally considered unsatisfactory, and an emphasis on surveillance and associated control measures as well as a focus on prevention in public health messages are critical. This review addresses the evolving epidemiology 
of WNV and summarizes the recent changes in classification as well as updates the current understanding of WNV clinical syndromes and viral-specific treatments. It also addresses opportunities for prevention, with particular emphasis on personal protective strategies.

\section{Virology}

WNV is a mosquito-borne flavivirus within the family Flaviviridae. The genus Flavivirus is comprised of more than 70 recognized viruses, including some of the most significant arboviral pathogens of humans. ${ }^{1} \mathrm{WNV}$ virions are spherical with a diameter of $50 \mathrm{~nm}$, consisting of a dense core with an adherent lipid envelope. ${ }^{1,2}$ The ribonucleic acid (RNA) genome is linear, plus sense, single-stranded, and approximately $11 \mathrm{~kb}$ long, with a clustering of coding regions for structural proteins at the $5^{\prime}$ end and nonstructural proteins at the $3^{\prime}$ end. Replication takes place in host cell cytoplasm, with the entire genomic RNA translated into a large polyprotein, which is subsequently cleaved into the functional structural and nonstructural proteins by cellular and viral proteins.

WNV is a member of the Japanese encephalitis virus serocomplex, sharing cross-neutralization antibodies with other important viruses that cause encephalitis in humans, including Japanese encephalitis virus, St Louis encephalitis virus, and Murray Valley encephalitis virus. In addition, WNV shares cross-neutralization antibodies with viruses that are either rare or less well-established causes of disease in humans, including Usutu, Kokobera, Stratford, Alfuy, Koutango, Yaounde, and Cacipacore viruses. ${ }^{3,4}$

\section{Changing epidemiology}

WNV was first isolated in December 1937, from a 37-yearold, febrile woman in the West Nile district in the Northern Province of Uganda, during an epidemiological study defining the endemic zone of yellow fever. ${ }^{5}$ Serum from the febrile case was inoculated intracerebrally in mice, with the subsequent viral particles shown to cause an encephalitic illness in selected vertebrate hosts, including mice and rhesus monkeys.

The virus was not isolated again until the 1950s, when the first WNV epidemics were described in Israel and Egypt. ${ }^{6,7}$ A large-scale epidemiological study in the 1950s identified seroprevalence rates as high as $61 \%$ in the Nile Delta of Egypt. ${ }^{8}$ This report was the first to describe the seasonal pattern of WNV transmission, with the peak in the midsummer, and to propose the natural enzootic cycle of WNV transmission between mosquitoes and birds. ${ }^{8}$ The potential for significant illness in equines was also recognized in early epidemiological studies. ${ }^{8-10}$ Despite the emerging understanding of the epidemiology, the prevailing view in the latter half of the 20th century was that WNV was a self-limiting and nonserious illness, predominantly in children, which rarely manifested with definite signs of encephalitis. These views were reinforced by observations following the accidental laboratory acquisition of infections, as well as the experimental infection of patients with advanced cancers, in whom the symptoms, when they were observed, were typically limited to fever and occasional headache. ${ }^{8,11}$ Prior to the 1990s, the WNV threat to public health was not widely appreciated. This was despite the recognition of the increasing geographical range as well as the ongoing and emerging sporadic cases of human disease reported in Egypt, Israel, France, South Africa, Russia, Spain, India, as well as in Australia, where Kunjin virus was subsequently reassigned to the WNV group. ${ }^{11-14}$

There seemed to be a shift in WNV epidemiology in the late 1990s, with more frequent descriptions of epidemics in urban areas of Europe and the Middle East that were associated with a notable increase of human neuroinvasive disease. ${ }^{11,15}$ The preponderance of neuroinvasive disease in immunologically naïve populations was associated with high morbidity and mortality, particularly in the elderly. In 1999, WNV was first discovered in the Americas, ${ }^{16}$ and while there is strong phylogenetic evidence that the emergent New York (NY99) strain arose from a strain in circulation in Israel since 1998, it remains unclear how the virus came to be introduced. ${ }^{17}$ Subsequently, WNV has disseminated to all 48 contiguous states of the USA as well as to South America, the Caribbean, and all provinces of Canada. In 2012, there was a resurgence in human cases in North America to levels not seen in a decade, with 5,674 patients reported with clinical illness in the USA (compared with a nadir of 712 cases in 2011 ) and 428 clinical cases notified in Canada (with a nadir of five cases in 2010). ${ }^{18,19}$ North American WNV activity levels remained higher than historical averages in 2013, with 2,318 human disease cases reported in the US and 108 cases in Canada at the end of the transmission season. ${ }^{20,21}$

In Europe, there is a history of recognized WNV outbreaks, characterized by human neuroinvasive disease, dating back to the mid-1990s. ${ }^{22}$ However, since 2008, there has been an unprecedented increased WNV activity, including the sustained emergence of a lineage $2 \mathrm{WNV}$, with a rapid rise in the number of cases of neuroinvasive disease of animals and humans. ${ }^{23,24}$ In 2012, there was a peak of 937 WNV cases in Europe and surrounding countries, with ongoing activity 
in 2013, with preliminary data reporting $783 \mathrm{WNV}$ human cases, including 86 in Greece and 302 in Serbia. ${ }^{25}$

\section{Molecular epidemiology}

Phylogenetic classification of WNV remains dynamic, with the large increase in genome sequence and surveillance data in recent years. Present analysis supports that WNV aligns into at least seven lineages on the basis of nucleic acid homology, with the major lineages diverging by $25 \%-30 \%$ nucleotide differences., ${ }^{4,17,26}$ Only lineage 1 and 2 have been implicated in human disease. As outlined below, the phylogenetic classification does not consistently correlate with the geographical distribution of WNV, which may be attributed to the broad dissemination of the virus by migrating bird species.

\section{Lineage I}

Lineage $1 \mathrm{WNV}$ has a wide geographical distribution, including Africa, Europe, Australia, Asia, North and Central America, as well as the Middle East. ${ }^{17}$ Lineage 1 can be further divided into three sublineages, or clades (1a, 1b, 1c). Sublineage $1 \mathrm{a}$ is the most widely distributed, occurring in Africa, Europe, the Americas (including the NY99 strain), and the Middle East. In 2011, a sublineage 1a WNV was isolated from the serum of a febrile patient for the first time in India, during an epidemic of neuroinvasive disease. ${ }^{27}$ Until recently, sublineage 1a contained all isolates associated with outbreaks of human encephalitis, including the ongoing epidemic in North America. ${ }^{17}$ Sublineage 1b, also referred to as Kunjin virus, is an uncommon cause of human disease endemic to Australia and is probably also found in South East Asia and Papua New Guinea. ${ }^{28,29}$ While few human cases are reported, a major epidemic of illness in horses was reported in southeast Australia in $2011 .^{30}$ Sublineage $1 \mathrm{c}$ is only found in India. It has been proposed that isolates previously classified as sublineage $1 \mathrm{c}$ be reassigned to a new lineage $5 .^{31}$

\section{Lineage 2}

Until the mid-2000s, WNV lineage 2 was predominantly limited to Africa, where it has been a cause of mild febrile illness in humans, rarely progressing to severe disease and typically not associated with outbreaks. ${ }^{17}$ However, in 2004 and 2005, WNV belonging to lineage 2 was first identified in wild birds in Hungary, with subsequent rapid spread to much of central Europe. ${ }^{32,33}$ These lineage 2 viruses have been implicated in avian, equine, and human cases of neuroinvasive disease with associated deaths, including cases reported in Russia, Hungary, Italy, and Greece., $46,34,35$
A large and ongoing epidemic of neuroinvasive disease in Greece has been attributed to lineage $2 \mathrm{WNV}$, which on whole genome sequencing was found to be highly similar to the 2004 strain isolated in Hungary. ${ }^{34,36}$ Lineages 1 and 2 WNV are now considered endemic in southeastern Europe, with an over $700 \%$ increase in cases reported in the region since $2009 .^{24}$

\section{Additional proposed lineages}

WNV belonging to lineage 3 was first isolated near the Austrian and Czech Republic border in 1997. Lineage 3 WNV has also been referred to as Rabensburg virus, named after the nearby Austrian town where the first infected Culex pipiens mosquitoes were isolated. ${ }^{33,37}$ On the basis of genomic and antigenic diversity, it has been suggested that Rabensburg virus be assigned a new species within the Japanese encephalitis virus group. ${ }^{33}$ Lineage 3 virus has not been isolated from humans, and the pathogenic potential remains uncertain, particularly as Rabensburg virus has been shown not to infect mammalian or avian cell cultures, nor infect experimentally exposed birds. ${ }^{38}$

Additional lineage subdivisions have been proposed for novel flavivirus isolates, including lineage $4 \mathrm{WNV}$, first isolated from a Dermacentor marginatus tick in the Caucasus Mountains in Russia. ${ }^{39}$ As outlined above, lineage 5 WNV has been proposed for a group of human and mosquito isolates circulating in India as early as the 1950s and cluster to form sublineage 1c.,31 Lineage $6 \mathrm{WNV}$ has been proposed for virus isolated from C. pipiens mosquitoes in southern Spain in 2006 and is most closely related to lineage $4 .{ }^{40}$ Koutango, first isolated in Senegal, is currently recognized as a separate species but may represent an additional WNV lineage $7 .{ }^{41}$ The human pathogenicity of lineages 4,6 , and $7 \mathrm{WNV}$ is poorly understood, with human infection not reported.

\section{Ecology}

West Nile virus is maintained in the environment through transmission cycles involving birds and mosquitoes. While over 60 species of mosquito have been implicated in the transmission of WNV, the key vector species are those belonging to the genus Culex. ${ }^{42}$ In particular, mosquitoes belonging to the C. pipiens complex (ie, C. pipiens pipiens, C. pipiens molestus, and Culex quinquefasciatus), which are found extensively in North America and Europe, drive transmission of WNV, with variable behaviors and physiologies displayed by the individual species, influencing the local transmission risk. ${ }^{43}$ These mosquitoes are predominantly ornithophilic ("bird feeding") species and are considered efficient enzootic vec- 
tors (ie, bird-to-mosquito-to-bird transmission). However, as the mosquitoes are often abundant and closely associated with urban environments, and with the immature stages of many species found in aquatic habitats within man-made structures, their proximity to humans results in an increased risk to act as epizootic vectors (ie, bird-to-mosquito-to-human transmission). A shift to improved water conservation strategies in urban areas (ie, the construction of wastewater and wildlife conservation wetlands) may further influence WNV risk, with changes to vector and reservoir host populations. ${ }^{44,45}$

While Culex spp. mosquitoes are the primary vectors, in some regions, a range of mosquito species belonging to other genera may play secondary roles in transmission cycles. Some other species may bite birds but generally prefer mammalian hosts. This shifting or, at least, highly variable, host-feeding preference makes the prediction of outbreaks difficult. It is important to note that while laboratory studies may demonstrate that Aedes spp. mosquitoes may be efficient WNV vectors, ${ }^{46}$ when host-seeking preferences are considered under field conditions, there are likely to be ecological barriers to their importance in local outbreaks. When assessing local risk factors, it is important that a range of biological and ecological risk factors are taken into account.

In North America, laboratory studies consistently demonstrate that Culex spp. mosquitoes are efficient enzootic or amplifying vectors. ${ }^{46,47}$ Similarly, in Europe, Culex spp. mosquitoes have been identified as the primary vectors of WNV. ${ }^{13}$ However, it is important to note that while members of the $C$. pipiens complex occur in both North American and Europe, there are differences in other Culex spp. between and within the two regions that must be considered when assessing local risks. For example, in North America, Culex tarsalis is considered one of the major vectors of WNV, while in some regions of Europe, Culex modestus has been implicated as a locally important vector. ${ }^{42,48}$ However, a range of endemic mosquitoes within North America and Europe may play a locally significant role in enzootic and/or epidemic transmission of WNV. These variations in risk may be driven by differences in the availability of suitable mosquito habitats, relative abundance of Culex spp. mosquitoes, and their host feeding preferences, with some species more likely to act as enzootic rather than epizootic vectors. ${ }^{49}$

Various migratory and indigenous avian species act to disseminate and amplify WNV, with the degree and duration of viremia varying by species. ${ }^{50}$ The high level of WNV viremia in susceptible avian hosts is sufficient to infect feeding mosquitoes and in experimental conditions, has been shown to be sufficient for bird-to-bird transmission. ${ }^{51}$ Death of avian hosts may be an early sign of WNV outbreaks, as was demonstrated in the 1999 North American outbreak. ${ }^{52}$ In contrast, as seen with the more recent introduction of lineage 2 virus into southeastern Europe and the spread of lineage 1 virus to South America, reports of sick or dead birds may be scarce. As a consequence, seroconversion of asymptomatic sentinel bird populations may be a useful component of local surveillance programs assisting the early detection of WNV activity.

\section{Clinical syndromes}

Although the vast majority of patients acquire WNV following the bite of an infected mosquito, other routes of transmission are described, including via blood transfusion, solid organ transplant, congenital infection, as well as laboratory accidents. ${ }^{53-56}$

Understanding of the clinical epidemiology of WNV infection is complicated by the high number of cases that are either asymptomatic or that fail to present to medical attention due to mild symptoms. Moreover, it is well established that genetic variation of the WNV is an important determinant of pathogenicity, including the propensity to invade the meninges. ${ }^{57,58}$ This variation in pathogenicity is seen in animal models ${ }^{57,59}$ but has also been demonstrated by the extent of human neuroinvasive disease seen with the epidemic strains in northern America and the Mediterranean Basin, versus the endemic strains of Africa and Australia. ${ }^{28-30,59}$ During the North American and European epidemics, serological surveys have estimated that approximately $20 \%$ of infected patients developed a febrile illness with flu-like symptoms, which characterizes West Nile fever. ${ }^{60-62}$ More recently, the symptomology of WNV infection has been better defined by a study of 576 patients identified with incidental WNV viremia on screening tests at the time of blood donation. ${ }^{63}$ It was found that only $26 \%$ of viremic patients developed West Nile Fever, defined as the presence of at least three of the indicator symptoms, comprised of headache, generalized weakness, fever, severe muscle pain, joint pain, chills, painful eyes, or new rash. Just over $50 \%$ of viremic blood donors reported at least one symptom, with the most common complaints being headache and generalized weakness, with approximately half of symptomatic patients reporting fever. Of the $44 \%$ of viremic patients who sought medical care due to their symptoms, only $5 \%$ were diagnosed with West Nile fever. ${ }^{63}$

Overall, less than $1 \%$ of individuals infected with epidemic WNV will develop neuroinvasive disease, although the proportion increases with age. ${ }^{64,65}$ Neuroinvasive disease can 
be broadly classified into three groups comprising meningitis, encephalitis, and a rarer syndrome of flaccid paralysis. ${ }^{65}$ Patients may present with overlapping syndromes, including meningoencephalitis. WNV meningitis is characterized by fever and signs of meningeal irritation, including headache, neck stiffness, and photophobia. Encephalitis presents with a wide clinical range, from a mild, self-limited confusion state to altered level of consciousness with associated focal neurological signs, including ataxia, tremor, and occasionally seizures, coma, and death. ${ }^{65}$ Mortality associated with epidemic WNV encephalitis, in both North America and Greece, is approximately $20 \%,{ }^{23,66,67}$ and in one large community-based study, only one-fifth of patients diagnosed with WNV encephalitis returned to their prehospital level of function. ${ }^{66}$ Acute flaccid paralysis occurs in as many as $17.5 \%$ of patients with neuroinvasive disease secondary to anterior myelitis caused by direct viral invasion of the anterior horn cells. ${ }^{68,69}$ Advancing age is strongly associated with an increased risk of neuroinvasive disease, with rates as high as one in 50 for patients over 65 years. ${ }^{23,64,70}$ Other risk factors for neuroinvasive disease include a history of cancer, diabetes, and alcohol abuse. ${ }^{66}$

Although patients rarely describe visual symptoms, chorioretinitis and other ocular manifestations of WNV are particularly common. ${ }^{71,72}$ Uncommon manifestations of WNV infection may include fulminant hepatitis, ${ }^{73}$ pancreatitis, ${ }^{74}$ rhabdomyolysis, ${ }^{75}$ myocarditis, ${ }^{76}$ myositis, and orchitis. ${ }^{77}$ Congenital infection is described in late pregnancy; however, on the available evidence, there does not appear to be a significantly increased rate of fetal anomalies following WNV infection during pregnancy. ${ }^{55,78}$

\section{Laboratory diagnosis Serology}

The mainstay of WNV diagnosis is the detection of immunoglobulin (Ig)M in serum or cerebral spinal fluid (CSF). Although IgM may be negative at the time of presentation, greater than $98 \%$ of symptomatic patients will have a positive serum IgM after the first week of illness. ${ }^{79} \mathrm{WNV}$ IgM may persist in the serum for years in some patients, which may hinder the diagnosis and surveillance of acute infections, particularly in the setting of annual seasonal outbreaks. ${ }^{80,81}$ The commercial IgM antibody capture enzyme-linked immunosorbent assay is the most widely used assay and can be applied to both serum and CSF. Occasional false positives may be seen in patients with previous Flavivirus infection or immunization. The highly specific plaque-reduction neutralizing antibody assay can be utilized in this setting but requires the referral of specimens to reference laboratories.

\section{Viral detection and isolation}

The use of nucleic acid detection techniques has provided an opportunity to diagnose WNV in patients prior to the production of specific IgM antibody, with the circulation of detectible levels of WNV RNA in blood, on average, 4 days prior to the first detection of IgM antibodies. ${ }^{82} \mathrm{WNV}$ nucleic acid detection has become a routine test for screening blood products in endemic areas, and the introduction of such measures in these areas has essentially eliminated WNV acquisition through the donated blood or organ supply. ${ }^{83}$ Isolation of WNV by culture of blood or CSF is possible; however, it is not routinely performed because of poor sensitivity secondary to low levels of viremia in humans and the early production of neutralizing antibodies.

\section{Treatment}

Despite the recent surge in research as well as growing public health concerns, no effective drug for the treatment of WNV has been developed. There is a clear need to develop therapies. Clinical trials for WNV-specific therapies have been problematic, particularly because of difficult trial logistics associated with the sporadic presentation of cases and the difficulties of predicting outbreaks from year to year. In addition, patients typically present late, may have delayed diagnosis, and are often elderly with medical comorbidities. ${ }^{70,84}$ Currently, guidelines recommend patients with WNV encephalitis receive supportive therapies followed by intensive rehabilitation. ${ }^{85}$ Once neuroinvasive disease is established, the focus shifts to the prevention of secondary brain injury by managing hypotension, hypoxemia, intracranial hypertension, hyperglycemia, anemia, as well as seizures. ${ }^{86}$ The role of corticosteroids in neuroinvasive disease remains controversial because of a lack of supporting evidence and concerns that immunosuppression may worsen outcomes. Three antiviral candidate therapies, including ribavirin, interferon $\alpha$ (IFN- $\alpha$ ), and WNV-specific immunoglobulin are discussed below. Emerging therapies that lack human data, including nucleic acid inhibition, peptides, and small molecules targeting viral translocation, replication, or protease activity, have been reviewed recently and are not discussed here. ${ }^{87,88}$

\section{Ribavirin}

Ribavirin is a broad-spectrum nucleoside analog with in vitro activity against a number of RNA and deoxyribonucleic acid 
(DNA) viruses and is most widely used in the treatment of hepatitis $\mathrm{C}$ and in immunosuppressed patients with respiratory syncytial virus (RSV). ${ }^{89-91}$ In vitro activity of high-dose ribavirin has been demonstrated for WNV in a number of studies. ${ }^{92-94}$ However, there is limited and inconsistent animal data, which has not clearly demonstrated ribavirin efficacy. In a mouse model, there was a protective effect seen when highdose ribavirin was used as prophylaxis or immediately following viral inoculation; however, an increased mortality was demonstrated in hamsters treated with ribavirin 2 days after inoculation..$^{92,95,96}$ There are no clinical trials assessing the role of ribavirin in humans with WNV infection. Following a large WNV outbreak in Israel in 2000, a retrospective review of 37 patients treated with ribavirin reported an increased mortality in the treated group; however, this may have been due to a bias of treating patients with more severe disease. ${ }^{97}$ The observed discordance between ribavirin in vitro and in vivo efficacy may be attributed to poor bioavailability and limited central nervous system (CNS) penetration. With an oral ribavirin dose of 2,400 $\mathrm{mg}$ per day, the achieved serum concentration was $12-40$ times below the concentration required for an in vitro WNV inhibitory effect. ${ }^{92,93}$ Further animal and human data needs to be accumulated before ribavirin can be recommended for the treatment of WNV. The American Society for Infectious Diseases encephalitis guidelines recommend against the use of ribavirin in patients with WNV encephalitis. ${ }^{85}$

\section{Interferon $\alpha$}

IFNs are naturally occurring immunoregulatory glycopeptides central in the innate host response to viral infection. IFN- $\alpha$ is a type 1 IFN which targets a broad range of human cells. The end result on these target cells includes immunoregulatory, antiviral, and antitumor effects. There are expanding therapeutic uses of IFN- $\alpha$, particularly in the management of hepatitis C. ${ }^{98,99}$ The inhibitory effect of IFN- $\alpha$ for WNV infection has been demonstrated in primate cell culture at a concentration that is readily achievable in human serum..$^{92}$ The protective role of IFNs following WNV infection may also be inferred by the marked increase in mortality in experimentally infected IFN- $\alpha / \beta$ receptordeficient mice. ${ }^{100}$ Further evidence of protection in animals can be extrapolated from a mouse model of the related St Louis encephalitis virus, where the early administration of IFN led to a significant reduction in mortality. ${ }^{101}$ More recently, it has been demonstrated that potent IFN-inducing RNA transcripts were protective for suckling and adult mice exposed to a lethal WNV challenge. ${ }^{102}$ The human evidence for the use of IFN- $\alpha$ is limited to case reports of meningoencephalitis, where the outcomes have been mixed. ${ }^{84,103-105}$ The highly variable and dynamic clinical course of WNV neuroinvasive disease warrants that these case reports be interpreted with caution. In addition, IFN does not penetrate into the CSF, so the biological mechanism for the reported response in established meningoencephalitis cases remains unexplained. Nevertheless, because of the superior effect of IFN- $\alpha$ over ribavirin in cell culture, the available safety data for human use, as well as the fact that supratherapeutic concentrations are readily achievable in human serum, IFN- $\alpha$ warrants further clinical trials in WNV-infected patients. The commencement of a randomized clinical trial of IFN- $\alpha-2 b$ in patients with WNV infection was reported in 2002, although to date, no results have been published. ${ }^{106}$

\section{Immunoglobulin}

Passive immunity, in the form of pooled immunoglobulin or specific monoclonal antibodies, has proven efficacy in the treatment of several flaviviruses, including in animal models of WNV. ${ }^{107-109}$ In theory, neurotropic viruses, including WNV, may be more susceptible to antibody-mediated immunity than to cell-mediated immune responses because the neuron lacks the major histocompatibility complex-class I molecules, thereby evading the immune surveillance component of the cell response. In the 1970 s, the relative importance of humoral immunity compared with cellular immune response to WNV infection was assessed in a study where the mouse immune system was ablated with cyclophosphamide 1 day after experimental infection with WNV. It was possible to rescue $94 \%$ of mice if immune serum was given on day 1 or $2,82 \%$ with treatment on day 5 or 6 , but only $22 \%$ if treated on day 8 or 10 (compared with $3 \%$ survival in controls) and no significant survival benefit when immune-synergistic spleen cells were given after day $2 .{ }^{110} \mathrm{~A}$ consistent finding in WNV animal studies is that the timing of immunoglobulin intervention is key, if the clinical course is to be modified. Early treatment (day 1-2 post infection), typically prior to the development of clinically apparent disease, is associated with a near $100 \%$ survival in both mice and hamsters, but the therapeutic benefit is markedly reduce when delayed beyond 2-5 days. ${ }^{107,108}$ The published human data is limited to case reports of patients, often treated late in the course of illness, with mixed clinical outcomes. ${ }^{11-113}$ A Phase I/II clinical trial (ClinicalTrials.gov identifier NCT00068055) assessing the safety and effectiveness of immunoglobulin containing WNV antibodies in patients with or at high risk of neuroinvasive disease was terminated in 2006, and study data are yet to be 
reported. ${ }^{114}$ At present, with the possible exception of rare clinical scenarios, such as the use of immunoglobulin as early prophylaxis following defined exposures in blood or organ recipients, ${ }^{115}$ the published data remains insufficient to recommend routine immunoglobulin for the treatment of WNV infection.

\section{Opportunities for prevention}

Reducing the risks of WNV to the community requires an integrated approach incorporating mosquito control, modification of human and environmental factors, as well as active surveillance programs. While vaccination of horses has been widely implemented in some endemic regions, no vaccine for humans has been registered.

\section{Vector control and personal protection}

A wide range of mosquito-control strategies are available that target immature and adult mosquito populations. However, the most appropriate strategy will vary between regions and should be determined based on a site-specific understanding of vectors, including their habitat associations and reservoir-host dynamics. Beyond the use of insecticides by local authorities, households and individuals can substantially reduce WNV risk by ensuring that opportunities for mosquito production from local urban habitats are reduced and that personal protective measures are employed.

Individual responsibility is likely to provide the first line of defense against WNV. A range of personal protective measures are available, including the use of bed nets, insect repellents, as well as mosquito traps and other devices. The effectiveness of personal protective measures to prevent mosquito bites has been reviewed. ${ }^{16,117}$ Insect repellents containing $\mathrm{N}, \mathrm{N}$-diethyl-3-methylbenzamide (DEET), 2-(2-hydroxyethyl)-1-piperidinecarboxylic acid 1-methylpropyl ester (icaridin), and p-methane 3, 8-diol (PMD) have all been demonstrated, in laboratory and field testing, to prevent bites from a range of mosquito species. These products have been shown to have minimal adverse health effects on humans. ${ }^{118}$ Even though these products can prevent mosquito bites, a recent study from North America indicated that repellent use was not a significant factor influencing WNV risk. ${ }^{119}$ This result contrasts with earlier studies that indicated a positive relationship between insect repellent use and lower WNV seroprevalence. ${ }^{60}$ Even in the absence of quantitative studies supporting a link between insect repellent use and low WNV infection risk, the strong evidence that repellents do prevent mosquito bites provides sufficient support that personal protective measures should be encouraged, to assist in reducing the risks of WNV.

\section{Surveillance}

To reduce the risks of WNV, adequate surveillance programs must be in place. Whether it is mosquito control activities or the promotion of personal protective measures, operational and communication elements of all approaches must be informed by appropriate surveillance of the vectors, virus, and animal hosts, including humans. Surveillance of vector populations can be done in a number of ways but should be focused on the collection of primarily Culex spp. mosquitoes. A combination of adult host-seeking and oviposition traps are likely to collect sufficient data to assist local management of WNV risk. ${ }^{120}$ The first evidence of WNV activity may be identified through serosurveillance of sentinel animals, as part of arboviral surveillance programs, by the death of wild bird populations or by identification of symptomatic disease in other mammalian species, particularly horses. ${ }^{17,30,121}$ Screening of donated blood products in endemic areas has also emerged as an important surveillance tool for human WNV activity. Preparedness and awareness amongst local authorities is critical, but there are often substantial differences in practice between regional jurisdictions. ${ }^{122}$

\section{Predicting outbreaks}

It can be a complex task determining predictive models for WNV outbreaks. Notwithstanding differences in mosquito abundance and diversity between and within regions, climatic conditions that drive extrinsic incubation periods within mosquitoes may vary with the relationship between environmental temperature and dissemination rates of infection. ${ }^{123}$ With recent epidemics of WNV in Europe and North America, studies have identified environmental conditions as potentially important drivers of virus activity, including case-controlled studies in North America that have identified a high risk associated with urban environments. ${ }^{119,124,125}$ Changing environmental conditions may also influence reservoir host populations, including the migration of bird populations into new regions or other changes that bring avian host, mosquito vectors, and susceptible human populations into close proximity.

While much effort has been placed on developing predictive models of WNV activity in North America, ${ }^{120,126}$ outbreaks have remained unpredictable. ${ }^{127}$ Broad models that allow for the prediction of outbreaks across countries or continents are unlikely to be developed as the impact of urbanization and environmental change will not be 
homogenous, even in neighboring regions. ${ }^{128}$ However, there remains scope for the development of location-specific statistical and mathematic models to assist in the prediction of outbreaks. ${ }^{129}$

\section{Vaccines}

Despite the widespread use of effective equine vaccines and expanding experience with avian vaccination for pets and exotic species, no human vaccine is currently available. ${ }^{130}$ Nevertheless, a number of candidate vaccines have undergone initial safety and dosing trials in humans. ${ }^{131-133}$ An important barrier to the further development of WNV vaccines is the cost-benefit of such an intervention. It has been suggested that universal vaccination programs are unlikely to be cost-effective. ${ }^{134}$ The vaccine cost-benefit may be more favorable if the elderly population was targeted, given the propensity of neuroinvasive disease in this population. For this reason, the development of a vaccine for human use will have to include safety and efficacy studies in the elderly population. In addition, the recent emergence of new lineage 2 viruses causing human and animal disease in Europe requires that vaccines must be efficacious against multiple WNV variants. ${ }^{130}$

\section{Conclusion}

Over the last two decades WNV has demonstrated its capacity to evolve and to exploit new and changing environments. Accompanying the expansion of WNV into new regions, has been a resurgence in endemic areas, with strains harboring increased virulence, as demonstrated by significant morbidity and mortality in mammalian hosts, including humans. The complex epidemiology as well as limitations in serological diagnosis provides significant challenges to the establishment of effective surveillance for WNV. There is an urgent need to develop effective antiviral therapy for WNV. New agents need to be assessed for efficacy but also their capacity to enter the CNS.

It is unlikely that regionally specific outbreaks can be confidently predicted; therefore, in response to the threat that substantial outbreaks will continue to occur, health authorities must remain vigilant in their surveillance, treatment, and provision of personal-protection advice. Current surveillance efforts should focus on the early detection of WNV activity in mosquito, avian, and horse populations. Cooperation between entomologists, veterinarians, physicians, and public health practitioners, with rapid sharing of information, will form the cornerstone of effective and timely population intervention.

\section{Disclosure}

The authors report no conflicts of interest in this work.

\section{References}

1. White DO, Fenner F. Medical Virology. 4th ed. San Diego, CA: Academic Press; 1994.

2. Deubel V, Fiette L, Gounon P, et al. Variations in biological features of West Nile viruses. Ann N Y Acad Sci. 2001;951:195-206.

3. De Madrid AT, Porterfield JS. The flaviviruses (group B arboviruses): a cross-neutralization study. J Gen Virol. 1974;23(1):91-96.

4. May FJ, Davis CT, Tesh RB, Barrett AD. Phylogeography of West Nile virus: from the cradle of evolution in Africa to Eurasia, Australia, and the Americas. JVirol. 2011;85(6):2964-2974.

5. Smithburn KC, Hughes TP, Burke AW, Paul JH. A neurotropic virus isolated from the blood of a native of Uganda. Am J Trop Med Hyg. 1940;20:471-472.

6. Melnick JL, Paul JR, Riordan JT, Barnett VH, Goldblum N, Zabin E. Isolation from human sera in Egypt of a virus apparently identical to West Nile virus. Proc Soc Exp Biol Med. 1951;77(4):661-665.

7. Bernkopf $\mathrm{H}$, Levine $\mathrm{S}$, Nerson R. Isolation of West Nile virus in Israel. J Infect Dis. 1953;93(3):207-218.

8. Hurlbut HS, Rizk F, Taylor RM, Work TH. A study of the ecology of West Nile virus in Egypt. Am J Trop Med Hyg. 1956;5(4):579-620.

9. Murgue B, Murri S, Zientara S, Durand B, Durand JP, Zeller H. West Nile outbreak in horses in southern France, 2000: the return after 35 years. Emerg Infect Dis. 2001;7(4):692-696.

10. Joubert L, Oudar J, Hannoun C, et al. [Epidemiology of the West Nile virus: study of a focus in Camargue. IV. Meningo-encephalomyelitis of the horse]. Ann Inst Pasteur (Paris). 1970;118(2):239-247. French.

11. Sejvar JJ. West Nile virus: an historical overview. Ochsner J. 2003;5(3):6-10.

12. Jupp PG, Blackburn NK, Thompson DL, Meenehan GM. Sindbis and West Nile virus infections in the Witwatersrand-Pretoria region. $S$ Afr Med J. 1986;70(4):218-220.

13. Hubálek Z, Halouzka J. West Nile fever - a reemerging mosquito-borne viral disease in Europe. Emerg Infect Dis. 1999;5(5):643-650.

14. Heinz F, Collett MS, Purcell RH, et al. Family Flaviviridae. In: Van Regenmortel MH, Fauquet CM, Bishop DH, et al (editors). Virus taxonomy, Seventh report of the International Committee for the Taxonomy of Viruses. San Diego, CA: Academic Press; 2000;859-878.

15. Tsai TF, Popovici F, Cernescu C, Campbell GL, Nedelcu NI. West Nile encephalitis epidemic in southeastern Romania. Lancet. 1998;352(9130):767-771

16. Nash D, Mostashari F, Fine A, et al. The outbreak of West Nile virus infection in the New York city area in 1999. N Engl J Med. 2001;344(24):1807-1814.

17. Lanciotti RS, Roehrig JT, Deubel V, et al. Origin of the West Nile virus responsible for an outbreak of encephalitis in the northeastern United States. Science. 1999;286(5448):2333-2337.

18. BC Centre for Disease Control. West Nile Virus Activity in British Columbia Surveillance Program Results 2012. Vancouver, BC: Provincial Health Services Authority; 2013.

19. Centers for Disease Control and Prevention (CDC). West Nile virus and other arboviral diseases - United States, 2012. MMWR Morb Mortal Wkly Rep. 2013;62(25):513-517.

20. cdc.gov [homepage on the Internet]. West Nile virus disease cases and presumptive viremic blood donors by state - United States, 2013. Centers for Disease Control and Prevention; 2013 [updated January 7, 2014; cited December 30, 2013]. Available from: http://www.cdc.gov/ westnile/statsMaps/preliminaryMapsData/. Accessed March 1, 2014.

21. phac-aspc.gc.ca [homepage on the Internet]. West Nile virus MONITOR2013 human surveillance. Public Health Agency of Canada; 2013 [updated November 21, 2013; cited December 30, 2013]. Available from: http://www.phac-aspc.gc.ca/wnv-vwn/mon-hmnsurv-eng.php. Accessed March 1, 2014. 
22. Pradier S, Lecollinet S, Leblond A. West Nile virus epidemiology and factors triggering change in its distribution in Europe. Rev Sci Tech. 2012;31(3):829-844.

23. Danis K, Papa A, Papanikolaou E, et al. Ongoing outbreak of West Nile virus infection in humans, Greece, July to Aug 2011. Euro Surveill. 2011;16(34):1-5.

24. European Centre for Disease Prevention and Control. Annual Epidemiological Report 2012. Reporting on 2010 Surveillance Data and 2011 Epidemic Intelligence Data. Stockholm: European Centre for Disease Prevention and Control; 2013.

25. ecdc.europa.eu [homepage on internet]. Reported cases for West Nile fever for the EU and neighbouring countries: 2013. European Centre for Disease Prevention and Control; 2013 [cited December 30, 2013]. Available from: http:/www.ecdc.europa.eu/en/healthtopics/west_nile_fever/ west-nile-fever-maps/pages/index.aspx. Accessed March 20, 2014.

26. Papa A, Bakonyi T, Xanthopoulou K, Vázquez A, Tenorio A, Nowotny N. Genetic characterization of West Nile virus lineage 2, Greece, 2010. Emerg Infect Dis. 2011;17(5):920-922.

27. Balakrishnan A, Butte DK, Jadhav SM. Complete genome sequence of west nile virus isolated from alappuzha district, kerala, India. Genome Announc. 2013;1(3):1-2.

28. Gray TJ, Burrow JN, Markey PG, et al. West Nile virus (Kunjin subtype) disease in the northern territory of Australia - a case of encephalitis and review of all reported cases. Am J Trop Med Hyg. 2011;85(5):952-956.

29. Hall RA, Scherret JH, Mackenzie JS. Kunjin virus: an Australian variant of West Nile? Ann N Y Acad Sci. 2001;951:153-160.

30. Frost MJ, Zhang J, Edmonds JH, et al. Characterization of virulent West Nile virus Kunjin strain, Australia, 2011. Emerg Infect Dis 2012;18(5):792-800.

31. Bondre VP, Jadi RS, Mishra AC, Yergolkar PN, Arankalle VA. West Nile virus isolates from India: evidence for a distinct genetic lineage. J Gen Virol. 2007;88(Pt 3):875-884.

32. Bakonyi T, Ivanics E, Erdélyi K, et al. Lineage 1 and 2 strains of encephalitic West Nile virus, central Europe. Emerg Infect Dis. 2006;12(4):618-623.

33. Bakonyi T, Hubálek Z, Rudolf I, Nowotny N. Novel flavivirus or new lineage of West Nile virus, central Europe. Emerg Infect Dis. 2005;11(2):225-231.

34. Barzon L, Papa A, Pacenti M, et al. Genome sequencing of West Nile Virus from human cases in Greece, 2012. Viruses. 2013;5(9):2311-2319.

35. Magurano F, Remoli ME, Baggieri M, et al. Circulation of West Nile virus lineage 1 and 2 during an outbreak in Italy. Clin Microbiol Infect. 2012;18(12):E545-E547.

36. McMullen AR, Albayrak H, May FJ, Davis CT, Beasley DW, Barrett AD. Molecular evolution of lineage 2 West Nile virus. J Gen Virol. 2013;94(Pt 2):318-325.

37. Hubálek Z, Halouzka J, Juricová Z, Sebesta O. First isolation of mosquito-borne West Nile virus in the Czech Republic. Acta Virol. 1998;42(2):119-120

38. Aliota MT, Jones SA, Dupuis AP, Ciota AT, Hubalek Z, Kramer LD. Characterization of Rabensburg virus, a flavivirus closely related to West Nile virus of the Japanese encephalitis antigenic group. PLoS One. 2012;7(6):e39387.

39. Lvov DK, Butenko AM, Gromashevsky VL, et al. West Nile virus and other zoonotic viruses in Russia: examples of emerging-reemerging situations. Arch Virol Suppl. 2004;(18):85-96.

40. Vazquez A, Sanchez-Seco MP, Ruiz S, et al. Putative new lineage of West Nile virus, Spain. Emerg Infect Dis. 2010;16(3):549-552.

41. Pesko KN, Ebel GD. West Nile virus population genetics and evolution. Infect Genet Evol. 2012;12(2):181-190.

42. Colpitts TM, Conway MJ, Montgomery RR, Fikrig E. West Nile virus: biology, transmission, and human infection. Clin Microbiol Rev. 2012;25(4):635-648

43. Farajollahi A, Fonseca DM, Kramer LD, Marm Kilpatrick A. "Bird biting" mosquitoes and human disease: a review of the role of Culex pipiens complex mosquitoes in epidemiology. Infect Genet Evol. 2011;11(7):1577-1585.
44. Allan BF, Langerhans RB, Ryberg WA, et al. Ecological correlates of risk and incidence of West Nile virus in the United States. Oecologia. 2009;158(4):699-708.

45. Ezenwa VO, Milheim LE, Coffey MF, Godsey MS, King RJ, Guptill SC. Land cover variation and West Nile virus prevalence: patterns, processes, and implications for disease control. Vector Borne Zoonotic Dis. 2007;7(2):173-180.

46. Turell MJ, Dohm DJ, Sardelis MR, Oguinn ML, Andreadis TG, Blow JA. An update on the potential of north American mosquitoes (Diptera: Culicidae) to transmit West Nile Virus. J Med Entomol. 2005;42(1):57-62.

47. Turell MJ, O'Guinn ML, Dohm DJ, Jones JW. Vector competence of North American mosquitoes (Diptera: Culicidae) for West Nile virus. J Med Entomol. 2001;38(2):130-134.

48. Balenghien T, Fouque F, Sabatier P, Bicout DJ. Horse-, bird-, and human-seeking behavior and seasonal abundance of mosquitoes in a West Nile virus focus of southern France. J Med Entomol. 2006;43(5): 936-946.

49. Muñoz J, Ruiz S, Soriguer R, et al. Feeding patterns of potential West Nile virus vectors in south-west Spain. PLoS One. 2012;7(6):e39549.

50. Kilpatrick AM, LaDeau SL, Marra PP. Ecology of West Nile virus Transmission and its impact on birds in the western hemisphere. The Auk. 2007;124(4):1121-1136.

51. Komar N, Langevin S, Hinten S, et al. Experimental infection of North American birds with the New York 1999 strain of West Nile virus. Emerg Infect Dis. 2003;9(3):311-322.

52. Anderson JF, Andreadis TG, Vossbrinck CR, et al. Isolation of West Nile virus from mosquitoes, crows, and a Cooper's hawk in Connecticut. Science. 1999;286(5448):2331-2333.

53. Pealer LN, Marfin AA, Petersen LR, et al; West Nile Virus Transmission Investigation Team. Transmission of West Nile virus through blood transfusion in the United States in 2002. N Engl J Med. 2003;349(13): 1236-1245.

54. Nett RJ, Kuehnert MJ, Ison MG, Orlowski JP, Fischer M, Staples JE. Current practices and evaluation of screening solid organ donors for West Nile virus. Transpl Infect Dis. 2012;14(3):268-277.

55. O'Leary DR, Kuhn S, Kniss KL, et al. Birth outcomes following West Nile Virus infection of pregnant women in the United States: 2003-2004. Pediatrics. 2006;117(3):e537-e545.

56. Venter M, Burt FJ, Blumberg L, Fickl H, Paweska J, Swanepoel R. Cytokine induction after laboratory-acquired West Nile virus infection. N Engl J Med. 2009;360(12):1260-1262.

57. Beasley DW, Li L, Suderman MT, Barrett AD. West Nile virus strains differ in mouse neurovirulence and binding to mouse or human brain membrane receptor preparations. Ann NY Acad Sci. 2001;951:332-335.

58. Beasley DW, Davis CT, Whiteman M, Granwehr B, Kinney RM, Barrett AD. Molecular determinants of virulence of West Nile virus in North America. Arch Virol Suppl. 2004;(18):35-41.

59. Lim SM, Koraka P, van Boheemen S, et al. Characterization of the mouse neuroinvasiveness of selected European strains of West Nile virus. PLoS One. 2013;8(9):e74575.

60. Mostashari F, Bunning ML, Kitsutani PT, et al. Epidemic West Nile encephalitis, New York, 1999: results of a household-based seroepidemiological survey. Lancet. 2001;358(9278):261-264.

61. Solomon T. Flavivirus encephalitis. N Engl J Med. 2004;351(4): 370-378.

62. Hubálek Z. Comparative symptomatology of West Nile fever. Lancet. 2001;358(9278):254-255.

63. Zou S, Foster GA, Dodd RY, Petersen LR, Stramer SL. West Nile fever characteristics among viremic persons identified through blood donor screening. J Infect Dis. 2010;202(9):1354-1361.

64. Carson PJ, Borchardt SM, Custer B, et al. Neuroinvasive disease and West Nile virus infection, North Dakota, USA, 1999-2008. Emerg Infect Dis. 2012;18(4):684-686.

65. Kramer LD, Li J, Shi PY. West Nile virus. Lancet Neurol. 2007;6(2) $171-181$. 
66. Bode AV, Sejvar JJ, Pape WJ, Campbell GL, Marfin AA. West Nile virus disease: a descriptive study of 228 patients hospitalized in a 4-county region of Colorado in 2003. Clin Infect Dis. 2006;42(9): $1234-1240$.

67. Danis K, Papa A, Theocharopoulos G, et al. Outbreak of West Nile virus infection in Greece, 2010. Emerg Infect Dis. 2011;17(10): $1868-1872$.

68. Téllez-Zenteno JF, Hunter G, Hernández-Ronquillo L, Haghir E. Neuroinvasive West Nile virus disease in Canada. The Saskatchewan experience. Can J Neurol Sci. 2013;40(4):580-584.

69. Leis AA, Stokic DS. Neuromuscular manifestations of West Nile virus infection. Front Neurol. 2012;3:37.

70. Petersen LR, Brault AC, Nasci RS. West Nile virus: review of the literature. JAMA. 2013;310(3):308-315.

71. Garg S, Jampol LM. Systemic and intraocular manifestations of West Nile virus infection. Surv Ophthalmol. 2005;50(1):3-13.

72. Khairallah M, Ben Yahia S, Ladjimi A, et al. Chorioretinal involvement in patients with West Nile virus infection. Ophthalmology. 2004;111(11):2065-2070.

73. Georges AJ, Lesbordes JL, Georges-Courbot MC, Meunier DMY, Gonzalez JP. Fatal hepatitis from West Nile virus. Ann Inst Pasteur Virol. 1987(2);138:237-244.

74. Perelman A, Stern J. Acute pancreatitis in West Nile Fever. Am J Trop Med Hyg. 1974;23(6):1150-1152.

75. Montgomery SP, Chow CC, Smith SW, Marfin AA, O'Leary DR, Campbell GL. Rhabdomyolysis in patients with West Nile encephalitis and meningitis. Vector Borne Zoonotic Dis. 2005;5(3):252-257.

76. Pergam SA, DeLong CE, Echevarria L, Scully G, Goade DE. Myocarditis in West Nile Virus infection. Am J Trop Med Hyg. 2006;75(6):1232-1233.

77. Smith RD, Konoplev S, DeCourten-Myers G, Brown T. West Nile virus encephalitis with myositis and orchitis. Hum Pathol. 2004;35(2): 254-258.

78. Stewart RD, Bryant SN, Sheffield JS. West Nile virus infection in pregnancy. Case Rep Infect Dis. 2013;2013:351872.

79. Tilley PA, Fox JD, Jayaraman GC, Preiksaitis JK. Nucleic acid testing for west nile virus RNA in plasma enhances rapid diagnosis of acute infection in symptomatic patients. J Infect Dis. 2006;193(10): 1361-1364.

80. Murray KO, Garcia MN, Yan C, Gorchakov R. Persistence of detectable immunoglobulin $\mathrm{M}$ antibodies up to 8 years after infection with West Nile virus. Am J Trop Med Hyg. 2013;89(5):996-1000.

81. Papa A, Danis K, Athanasiadou A, Delianidou M, Panagiotopoulos T. Persistence of West Nile virus immunoglobulin M antibodies, Greece. J Med Virol. 2011;83(10):1857-1860.

82. Busch MP, Kleinman SH, Tobler LH, et al. Virus and antibody dynamics in acute west nile virus infection. J Infect Dis. 2008;198(7):984-993.

83. Busch MP, Tobler LH, Saldanha J, et al. Analytical and clinical sensitivity of West Nile virus RNA screening and supplemental assays available in 2003. Transfusion. 2005;45(4):492-499.

84. Sayao AL, Suchowersky O, Al-Khathaami A, et al. Calgary experience with West Nile virus neurological syndrome during the late summer of 2003. Can J Neurol Sci. 2004;31(2):194-203.

85. Tunkel AR, Glaser CA, Bloch KC, et al; Infectious Diseases Society of America. The management of encephalitis: clinical practice guidelines by the Infectious Diseases Society of America. Clin Infect Dis. 2008;47(3):303-327.

86. Kramer AH. Viral encephalitis in the ICU. Crit Care Clin. 2013;29(3): 621-649.

87. Diamond MS. Progress on the development of therapeutics against West Nile virus. Antiviral Res. 2009;83(3):214-227.

88. Baharuddin A, Hassan AA, Sheng GC, et al. Current approaches in antiviral drug discovery against the Flaviviridae family. Curr Pharm Des. Epub September 2, 2013.

89. European Association for the Study of the Liver. EASL Clinical Practice Guidelines: management of hepatitis $\mathrm{C}$ virus infection. J Hepatol. 2011;55(2):245-264.
90. Ghany MG, Nelson DR, Strader DB, Thomas DL, Seeff LB; American Association for Study of Liver Diseases. An update on treatment of genotype 1 chronic hepatitis $\mathrm{C}$ virus infection: 2011 practice guideline by the American Association for the Study of Liver Diseases. Hepatology. 2011;54(4):1433-1444.

91. Waghmare A, Campbell AP, Xie H, et al. Respiratory syncytial virus lower respiratory disease in hematopoietic cell transplant recipients: viral RNA detection in blood, antiviral treatment, and clinical outcomes. Clin Infect Dis. 2013;57(12):1731-1741.

92. Anderson JF, Rahal JJ. Efficacy of interferon alpha-2b and ribavirin against West Nile virus in vitro. Emerg Infect Dis. 2002;8(1): 107-108.

93. Jordan I, Briese T, Fischer N, Lau JY, Lipkin WI. Ribavirin inhibits West Nile virus replication and cytopathic effect in neural cells. J Infect Dis. 2000;182(4):1214-1217.

94. Morrey JD, Smee DF, Sidwell RW, Tseng C. Identification of active antiviral compounds against a New York isolate of West Nile virus. Antiviral Res. 2002;55(1):107-116.

95. Morrey JD, Day CW, Julander JG, Blatt LM, Smee DF, Sidwell RW. Effect of interferon-alpha and interferon-inducers on West Nile virus in mouse and hamster animal models. Antivir Chem Chemother. 2004;15(2):101-109.

96. Loginova SIa, Borisevich SV, Pashchenko IuA, Bondarev VP. [Ribavirin prophylaxis and therapy of experimental West Nile fever]. Antibiot Khimioter. 2009;54(11-12):17-20. Russian.

97. Chowers MY, Lang R, Nassar F, et al. Clinical characteristics of the West Nile fever outbreak, Israel, 2000. Emerg Infect Dis. 2001;7(4): 675-678.

98. Borden EC, Sen GC, Uze G, et al. Interferons at age 50: past, current and future impact on biomedicine. Nat Rev Drug Discov. 2007;6(12): 975-990.

99. Brassard DL, Grace MJ, Bordens RW. Interferon- $\alpha$ as an immunotherapeutic protein. J Leukoc Biol. 2002;71(4):565-581.

100. Samuel MA, Diamond MS. Alpha/beta interferon protects against lethal West Nile virus infection by restricting cellular tropism and enhancing neuronal survival. J Virol. 2005;79(21):13350-13361.

101. Brooks TJ, Phillpotts RJ. Interferon-alpha protects mice against lethal infection with St Louis encephalitis virus delivered by the aerosol and subcutaneous routes. Antiviral Res. 1999;41(1):57-64.

102. Rodríguez-Pulido M, Martín-Acebes MA, Escribano-Romero E, et al. Protection against West Nile virus infection in mice after inoculation with type I interferon-inducing RNA transcripts. PLoS One. 2012;7(11):e49494.

103. Kalil AC, Devetten MP, Singh S, et al. Use of interferon-alpha in patients with West Nile encephalitis: report of 2 cases. Clin Infect Dis. 2005;40(5):764-766.

104. Chan-Tack KM, Forrest G. Failure of interferon alpha-2b in a patient with West Nile virus meningoencephalitis and acute flaccid paralysis. Scand J Infect Dis. 2005;37(11-12):944-946.

105. Lewis M, Amsden JR. Successful treatment of West Nile virus infection after approximately 3 weeks into the disease course. Pharmacotherapy. 2007;27(3):455-458.

106. Jackson AC. Therapy of West Nile virus infection. Can J Neurol Sci. 2004;31(2):131-134.

107. Agrawal AG, Petersen LR. Human immunoglobulin as a treatment for West Nile virus infection. J Infect Dis. 2003;188(1):1-4.

108. Morrey JD, Siddharthan V, Olsen AL, et al. Humanized monoclonal antibody against West Nile virus envelope protein administered after neuronal infection protects against lethal encephalitis in hamsters. J Infect Dis. 2006;194(9):1300-1308.

109. Ben-Nathan D, Gershoni-Yahalom O, Samina I, et al. Using high titer West Nile intravenous immunoglobulin from selected Israeli donors for treatment of West Nile virus infection. BMC Infect Dis. 2009;9:18.

110. Camenga DL, Nathanson N, Cole GA. Cyclophosphamide-potentiated West Nile viral encephalitis: relative influence of cellular and humoral factors. J Infect Dis. 1974;130(6):634-641. 
111. Levi ME, Quan D, Ho JT, Kleinschmidt-Demasters BK, Tyler KL, Grazia TJ. Impact of rituximab-associated B-cell defects on West Nile virus meningoencephalitis in solid organ transplant recipients. Clin Transplant. 2010;24(2):223-228.

112. Rhee C, Eaton EF, Concepcion W, Blackburn BG. West Nile virus encephalitis acquired via liver transplantation and clinical response to intravenous immunoglobulin: case report and review of the literature. Transpl Infect Dis. 2011;13(3):312-317.

113. Haley M, Retter AS, Fowler D, Gea-Banacloche J, O'Grady NP. The role for intravenous immunoglobulin in the treatment of West Nile virus encephalitis. Clin Infect Dis. 2003;37(6):e88-e90.

114. National Institute of Allergy and Infectious Diseases (NIAID). A phase I/II randomized, placebo-controlled trial to assess the safety and efficacy of intravenous immunoglobulin G (OMR-IGG-AM) containing high anti-West Nile virus antibody titers in patients with, or at high risk for progression to West Nile virus (WNV) encephalitis and/or myelitis. Available from: http://www.clinicaltrials.gov/ show/NCT00068055. NLM identifier: NCT00068055. Accessed March 20, 2014.

115. Morelli MC, Sambri V, Grazi GL, et al. Absence of neuroinvasive disease in a liver transplant recipient who acquired West Nile virus (WNV) infection from the organ donor and who received WNV antibodies prophylactically. Clin Infect Dis. 2010;51(4):e34-e37.

116. Goodyer LI, Croft AM, Frances SP, et al. Expert review of the evidence base for arthropod bite avoidance. J Travel Med. 2010;17(3): 182-192.

117. Debboun M, Strickman D. Insect repellents and associated personal protection for a reduction in human disease. Med Vet Entomol. 2013;27(1):1-9.

118. Goodyer L, Behrens RH. Short report: The safety and toxicity of insect repellents. Am J Trop Med Hyg. 1998;59(2):323-324.

119. Gibney KB, Colborn J, Baty S, et al. Modifiable risk factors for West Nile virus infection during an outbreak - Arizona, 2010. Am J Trop Med Hyg. 2012;86(5):895-901.

120. Kilpatrick AM, Pape WJ. Predicting human West Nile virus infections with mosquito surveillance data. Am J Epidemiol. 2013;178(5): 829-835.

121. Komar N. West Nile virus surveillance using sentinel birds. Ann NY Acad Sci. 2001;951:58-73.

122. Cito F, Narcisi V, Danzetta ML, et al. Analysis of surveillance systems in place in European mediterranean countries for West Nile Virus (WNV) and Rift Valley Fever (RVF). Transbound Emerg Dis. 2013;60(Suppl S2):S40-S44.
123. Dohm DJ, O'Guinn ML, Turell MJ. Effect of environmental temperature on the ability of Culex pipiens (Diptera: Culicidae) to transmit West Nile virus. J Med Entomol. 2002;39(1):221-225.

124. Beasley DW, Barrett AD, Tesh RB. Resurgence of West Nile neurologic disease in the United States in 2012: what happened? What needs to be done? Antiviral Res. 2013;99(1):1-5.

125. Paz S, Semenza JC. Environmental drivers of West Nile fever epidemiology in Europe and Western Asia - a review. Int J Environ Res Public Health. 2013;10(8):3543-3562.

126. Carney RM, Ahearn SC, McConchie A, et al. Early warning system for West Nile virus risk areas, California, USA. Emerg Infect Dis. 2011;17(8):1445-1454.

127. Zeller HG, Schuffenecker I. West Nile virus: an overview of its spread in Europe and the Mediterranean basin in contrast to its spread in the Americas. Eur J Clin Microbiol Infect Dis. 2004;23(3): $147-156$.

128. Morin CW, Comrie AC. Regional and seasonal response of a West Nile virus vector to climate change. Proc Natl Acad Sci U S A. 2013;110(39):15620-15625.

129. Chevalier V, Tran A, Durand B. Predictive modeling of West Nile virus transmission risk in the Mediterranean Basin: how far from landing? Int J Environ Res Public Health. 2014;11(1):67-90.

130. Beasley DW. Vaccines and immunotherapeutics for the prevention and treatment of infections with West Nile virus. Immunotherapy. 2011;3(2):269-285.

131. Durbin AP, Wright PF, Cox A, et al. The live attenuated chimeric vaccine $\mathrm{rWN} / \mathrm{DEN} 4 \Delta 30$ is well-tolerated and immunogenic in healthy flavivirus-naïve adult volunteers. Vaccine. 2013;31(48): $5772-5777$.

132. Dayan GH, Bevilacqua J, Coleman D, Buldo A, Risi G. Phase II, dose ranging study of the safety and immunogenicity of single dose West Nile vaccine in healthy adults $\geq 50$ years of age. Vaccine. 2012;30(47):6656-6664.

133. Ledgerwood JE, Pierson TC, Hubka SA, et al; VRC 303 Study Team. A West Nile virus DNA vaccine utilizing a modified promoter induces neutralizing antibody in younger and older healthy adults in a phase I clinical trial. J Infect Dis. 2011;203(10):1396-1404.

134. Kaiser J. Outbreak pattern stymies vaccine work. Science. 2012;337(6098):1030.
International Journal of General Medicine

\section{Publish your work in this journal}

The International Journal of General Medicine is an international peer-reviewed open-access journal that focuses on general and internal medicine, pathogenesis, epidemiology, diagnosis, monitoring and treatment protocols. The journal is characterized by the rapid reporting of reviews, original research and clinical studies across all disease areas.

\section{Dovepress}

A key focus is the elucidation of disease processes and management protocols resulting in improved outcomes for the patient. The manuscript management system is completely online and includes a very quick and fair peer-review system. Visit http://www.dovepress.com/ testimonials.php to read real quotes from published authors. 